\title{
Water Resource Management: Moving from Single Risk-Based Management to Resilience to Multiple Stressors
}

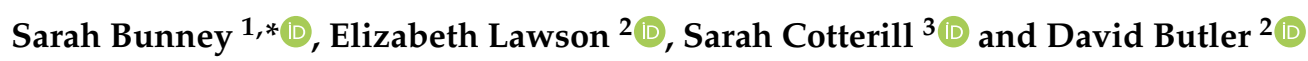 \\ 1 Department of Mathematics, Imperial College London, London SW7 2AZ, UK \\ 2 Centre for Water Systems, University of Exeter, Exeter EX4 4QF, UK; el403@exeter.ac.uk (E.L.); \\ d.butler@exeter.ac.uk (D.B.) \\ 3 School of Civil Engineering, University College Dublin, D04 V1W8 Dublin 4, Ireland; sarah.cotterill@ucd.ie \\ * Correspondence: s.bunney@imperial.ac.uk
}

check for updates

Citation: Bunney, S.; Lawson, E.; Cotterill, S.; Butler, D. Water Resource Management: Moving from Single Risk-Based Management to Resilience to Multiple Stressors. Sustainability 2021, 13, 8609. https://doi.org/ $10.3390 /$ su13158609

Academic Editor: Abel Silva Vieira

Received: 9 July 2021

Accepted: 30 July 2021

Published: 2 August 2021

Publisher's Note: MDPI stays neutral with regard to jurisdictional claims in published maps and institutional affiliations.

Copyright: (c) 2021 by the authors. Licensee MDPI, Basel, Switzerland. This article is an open access article distributed under the terms and conditions of the Creative Commons Attribution (CC BY) license (https:/ / creativecommons.org/licenses/by/ $4.0 /)$.

\begin{abstract}
Water resource management in the UK is multifaceted, with a complexity of issues arising from acute and chronic stressors. Below average rainfall in spring 2020 coincided with large-scale changes to domestic water consumption patterns, arising from the first UK-wide COVID-19 lockdown, resulting in increased pressure on nationwide resources. A sector wide survey, semi-structured interviews with sector executives, meteorological data, water resource management plans and market information were used to evaluate the impact of acute and chronic threats on water demand in the UK, and how resilience to both can be increased. The COVID-19 pandemic was a particularly acute threat: water demand increased across the country, it was unpredictable and hard to forecast, and compounding this, below average rainfall resulted in some areas having to tanker in water to 'top up' the network. This occurred in regions of the UK that are 'water stressed' as well as those that are not. We therefore propose a need to look beyond 'design droughts' and 'dry weather average demand' to characterise the management and resilience of future water resources. As a sector, we can learn from this acute threat and administer a more integrated approach, combining action on the social value of water, the implementation of water trading and the development of nationwide multi-sectoral resilience plans to better respond to short and long-term disruptors.
\end{abstract}

Keywords: COVID-19; drought; resilience; water demand

\section{Introduction}

England has endured three periods of national lockdowns (23/3/2020-10/05/2020, 05/11/2020-02/12/2020,06/01/2021-08/03/2021) [1] and prolonged periods of social restrictions as a result of the COVID-19 pandemic. Efforts to understand the pandemic's impact on water systems globally have focused on organisational response [2-4]; tracking the spread of SARS-CoV-2 in wastewater [5,6]; understanding changes to water consumption [7-10] and identifying how digitalisation could provide tools to reimagine water infrastructure to better cope with future needs, based on learning from the pandemic [11].

As the pandemic becomes a longer-term disruptor, the ability to meet organisational resilience objectives will remain a key challenge for the UK water sector. An organisation's resilience is underpinned by its capacity to mitigate, adapt, cope and learn from a crisis [12]. Many UK water companies perceived they had adequate business continuity plans and contingency arrangements in place [3]. However, pre-existing pandemic plans were inconsiderate of the scale of the crisis, resulting in the re-evaluation of business continuity and response plans by some organisations [4].

COVID-19 was found to be a 'threat multiplier' [4,13]. A combination of weather hazards, including reduced rainfall and higher than average temperatures, increased the complexity of resulting cascading effects for the water sector [4]. This was readily observed in the threat to potable water supply, with unpredictable demand patterns observed $[3,4]$. Water-intensive practices (such as the washing of groceries and more intensive personal 
hygiene) were adopted at the start of the lockdown to protect from COVID-19 infection [14]. Studies on consumption patterns $[7,8,10,15,16]$ revealed a delayed morning peak $(1-2 \mathrm{~h}$ later than the norm) and high water use throughout the day. Mass working from home relocated consumption from public spaces, such as offices and gyms, to the home [14]. Outdoor water consumption increased, as gardens became much more important for wellbeing and exercise, as a consequence of restrictions to travel and non-essential activities [14].

Furthermore, the pandemic highlighted pre-existing system vulnerabilities [4]. Applying the traditional risk management approach to plan and prepare for future water resource availability is challenging the ability to achieve resilience within the UK water sector $[3,4]$. While the anticipation of threats and hazards and the assessment of risk is a primary stage in the risk management process $[17,18]$, it is extremely difficult to determine with any certainty [19-21]. This approach is largely based on the assumption that all threats and hazards are known, and their impact and consequence can be predicted [22-24]. For those that are known, there is the potential for these to escalate into a series of cascading events where again the threats and hazards may be unknown [4,25-27].

In 2016, Water UK, the trade association that represents water companies in the UK conducted a study to assess the long-term challenges affecting water resource management in England and Wales [28]. The report highlighted how many parts of England are at serious risk of experiencing water shortages in the future. The pressure on water resources as a result of climate change, an increasing population and customer demand will challenge the ability of WSPs to achieve resilience of water supplies in the future. In 2018 the National Infrastructure Commission published a report outlining a vision to ensure the long-term resilience of UK water supplies to drought [29]. Building on the findings of the Water UK, 2016 study, a 'twin track' approach was proposed. The recommendations included reducing demand through compulsory metering and leakage reduction, investment to improve future water supply infrastructure, and the development of a national water transfer network. Actions to deliver the approach would be supported by the Department for the Environment, Food and Rural Affairs (Defra) through the development of a regulatory framework and through the 2019 review of water prices, conducted by the water regulator Ofwat.

However, the COVID-19 pandemic highlighted how a singular focus on 'design droughts' and 'dry weather average demand' to inform decision making regarding future water availability [30] has challenged the ability to respond to the immediate and acute threat imposed by a national lockdown. The rapidly changing dynamic situation and the complex interdependencies that exist between water availability and the societal influence on water demand demonstrated how acute and chronic threats can occur at the same time and result in a series of cascading events $[4,13]$. This was also evident in the water companies' responses to the 'Beast from the East' event during 2018 when a number of water companies experienced a series of pipe bursts following a prolonged period of sub-zero temperatures [31]. This resulted in the loss of the centralised water supply to over 200,000 customers [31]. In total, 36,000 people were left without a centralised water supply for over $24 \mathrm{hrs}$ and, in some instances, this extended over 5 days [32].

Water resources management provides a critical role in the development of a healthy society [33]. Throughout the COVID-19 pandemic frequent hand washing was strongly promoted by the World Health Organization to reduce the spread of the virus [34,35]. The availability of safe drinking water to ensure hygienic practices and sanitation are a fundamental part of this process and demonstrate the importance of water availability [7,33,36,37].

This study aims to analyse the UK Water Sector's organisational resilience to multiple stressors, by specifically evaluating the impact of COVID-19 and weather hazards observed during 2020 on water demand. We draw on findings from a sector-wide survey [3]; semi-structured interviews with senior managers from ten UK water companies [4]; and publicly available data from the Environment Agency, the Met Office, and UK water companies' websites, Water Resource Management Plans (WRMPs), water resources market 
information and social media accounts. Our analysis prompted the following research questions to be investigated:

1. Was domestic water demand affected by multiple stressors in 2020?

2. Were there regional differences in water availability?

3. What can we learn from an acute threat, such as COVID-19, to better prepare for chronic threats?

4. How can we increase resilience to the acute and chronic threats that water resources face?

\section{Materials and Method}

This paper forms a continuation of analysis to understand resilience within the water sector in England and Wales. This research includes survey data collected as part of Cotterill et al., (2020) [3] and semi-structured interview data collected by Lawson et al., (2021) [4]. The methodology for this data collection can be found within [3,4], respectively. A thematic analysis was conducted on the semi-structured interview data to extract themes relating to water demand and water trading.

Twitter posts and retweeted posts from the main, public accounts for seven WSPs in England and Wales were analysed for the period 16/03/2020 to 05/11/2020 (Figure 1). This corresponds with the period just before the first national lockdown and the start of the second lockdown. It also includes the spring, summer and start of the autumn season within the UK. Twitter posts were accessed on 10/4/2021. Each post was analysed according to whether it related to water saving measures. Seven WSPs were selected because it was possible to retrospectively read their posts on the WSP Twitter account page from 16/03/2020 to 05/11/2020. This was not possible for United Utilities, Dwr Cymru and Northumbrian Water where posts could only be viewed up to July 2020 and September 2020, respectively. These WSP Twitter accounts were not included within the analysis.

The standardised precipitation index (Figure 2C) was developed using the drought tool from CEH Wallingford [38]. The SPI period of 3 months ending in (SPI) since 1961 was selected for May $2020[39,40]$.

The total monthly rainfall $(\mathrm{mm})$ and mean temperature $\left({ }^{\circ} \mathrm{C}\right)$ for East and North East England, South East and Central South England, South West England and Wales, and the whole of the UK for 2017-2020 (Figure 3) was calculated using publicly accessible data from the Met Office [41]. Within the dataset the 'year ordered', the 'region' and the 'mean temp' or 'rainfall' were selected. Each dataset was downloaded, filtered by year and imported into R. The ggplot2 package was then used to develop the filled bar chart shown in Figure 3.

Water resources market information, submitted by WSPs to Ofwat in 2019, was analysed to understand the current situation regarding water availability in the UK and the forecast for the next 25 years (Figure 4). WSPs are required to provide a spreadsheet containing the principal market information for each water resource zone (WRZ) within their area. These are developed in accordance with guidelines developed by Ofwat and are available online [42]. The spreadsheets were accessed using the link on the Ofwat website to the WSP water resources market information spreadsheets [43]. Water resources market information spreadsheets were also accessed directly from the WSP, when the Ofwat link did not work. The zonal deficit was calculated using data taken from the baseline supply demand balance table. The supply demand balance forecast (which is the supply forecast minus demand forecast allowing for target headroom) was calculated as a percentage of demand (distribution input) for each year from 2020 to 2045. The resultant percentage of demand was then plotted as a heatmap using the Seaborn package within Python Jupyter Notebooks.

The Water Resource Management Plans (WRMPs) for the 10 main WSPs in England and Wales were reviewed [44-53] to understand whether WSPs consider water resource management in the context of multiple hazards and to understand the approach taken to water trading between WSPs in England and Wales. 


\section{Results and Discussion}

\subsection{Was Domestic Water Demand Affected by Multiple Stressors in 2020?}

All WSPs reported an increase in domestic demand as a result of the first 'national lockdown' (23/03/2020-10/05/2020) as customers stayed at home during a period of hot dry weather conditions (Table 1, Int-1). This was also highlighted in a collaborative study conducted by Artesia Consulting in collaboration with the Environment Agency and WSPs within England and Wales [14]. The study collated consumption data from the WSPs with weather and government policy data to quantify the impact of COVID19 on water demand [54]. Domestic water consumption was also analysed using smart meter data from January to May 2020 for one WSP area [10] which also demonstrated an increase in demand during the first national lockdown [10]. With schools and workplaces closed, WSPs observed a change in peak demand and diurnal flow patterns in response to changing customer behaviour (Table 1, Int-2). Peak demand patterns shifted with customers showering later in the morning and a more consistent high usage of water was observed throughout the day (Table 1, Int-2), [14]. WSPs discussed the challenges managing increased demand in locations such as commuter towns, where they would not expect a high demand during the day under 'normal' conditions (Table 1, Int-3), [54]. This also increased pressure at water treatment works managing an increased daily load (Table 1, Int-4).

As temperatures increased, WSPs observed a surge in demand; some reported a demand increase of over $40 \%$ towards the end of May (Table 1, Int-5). WSPs attributed the surge in demand to people enjoying the hot dry weather with more time being spent in the garden, customers purchasing hot tubs and the filling of paddling pools (Table 1, Int-6). This was also consistent with the findings from the Artesia study [54]. Indeed, the UK was experiencing the sunniest and driest May on record [55]. This created unexpected challenges with regard to water availability. Within the interviews, WSPs discussed the difficulties managing this sudden increase in demand and how they were close to exceeding production capacity at water treatment works (Table 1, Int-7). WSPs struggled when the demand was focused on certain areas within the region rather than spread across the whole company. The increase in water demand ' ... caught everyone out'. Despite the hot weather, people working from home and the increased use of water for handwashing, WSPs were not prepared for the sudden increase in water demand. This was coupled with a lack of understanding regarding customer behaviour and how this related to the huge variability in water demand experienced on a daily basis, even though the weather conditions were stable. However, there were also examples where WSPs used water tankers to manage demand. The problem was not due to a lack of water availability; there was '.. plenty of water in the reservoirs.' The WSP used the tankers to manage a peak in demand.

In some locations, sewage treatment works were experiencing higher loadings of sewage and 'operating closer to their limits'. In contrast, there were also locations where sewage treatment works were operating under capacity as a result of people working from home and not being in their normal work environment (Table 1, Int-8). This created added complications for water companies that rely on using waste to generate their own energy.

Table 1. Quotes relating to water demand during the COVID-19 pandemic, taken from semi-structured interviews conducted by Lawson et al. (2021).

\begin{tabular}{cc}
\hline Ref & Qualitative Explanation \\
\hline Int-1 & “...they are staying at home then add in that, there was a big heatwave that's what happened to our demand ... " \\
\hline Int-2 & "We have seen big changes to customer behaviour ... people are showering at 9 and not $7 \ldots$... \\
\hline Int-3 & "... and now they are not going into [Location] so the demand goes up in those places we are not used to ... " \\
\hline Int-4 & $\begin{array}{r}\text { "... that was putting a strain on some of our wastewater treatment works because they are having to cope with a lot } \\
\text { more load than they are used to." }\end{array}$ \\
\hline
\end{tabular}


Table 1. Cont.

\begin{tabular}{cr} 
Ref & Qualitative Explanation \\
\hline Int-5 & '... during the May bank holiday we saw demand increase 20\% that (sic) what we would ordinarily see on average. \\
Some areas went up to $40 \%$ higher.'
\end{tabular}

At the start of the national lockdown WSPs were using social media platforms like Twitter to reassure customers they were working hard to keep the water flowing during the crisis (Table 2, Tw-1). This platform was also used by WSPs to provide customers with information on how to save water (Figure 1). During March and April, tweets relating to water saving measures contained general information and advice with one WSP sharing 'top tips' for water saving in the home during lockdown. A third (34\%) of the water saving tweets in May (11/05/2020 - 15/05/2020) consisted of general information and advice relating to water saving week (Table 2, Tw-2). However, towards the end of May as the demand for water increased, the Twitter messages became more direct, asking customers to save water (Table $2, \mathrm{Tw}-3$ ). In total, $70 \%$ of WSPs included specific information regarding how much water was being pumped into the system (Table 2, Tw-4) and how the demand for water had created difficulties maintaining pressure in the system (Table 2, Tw-5).

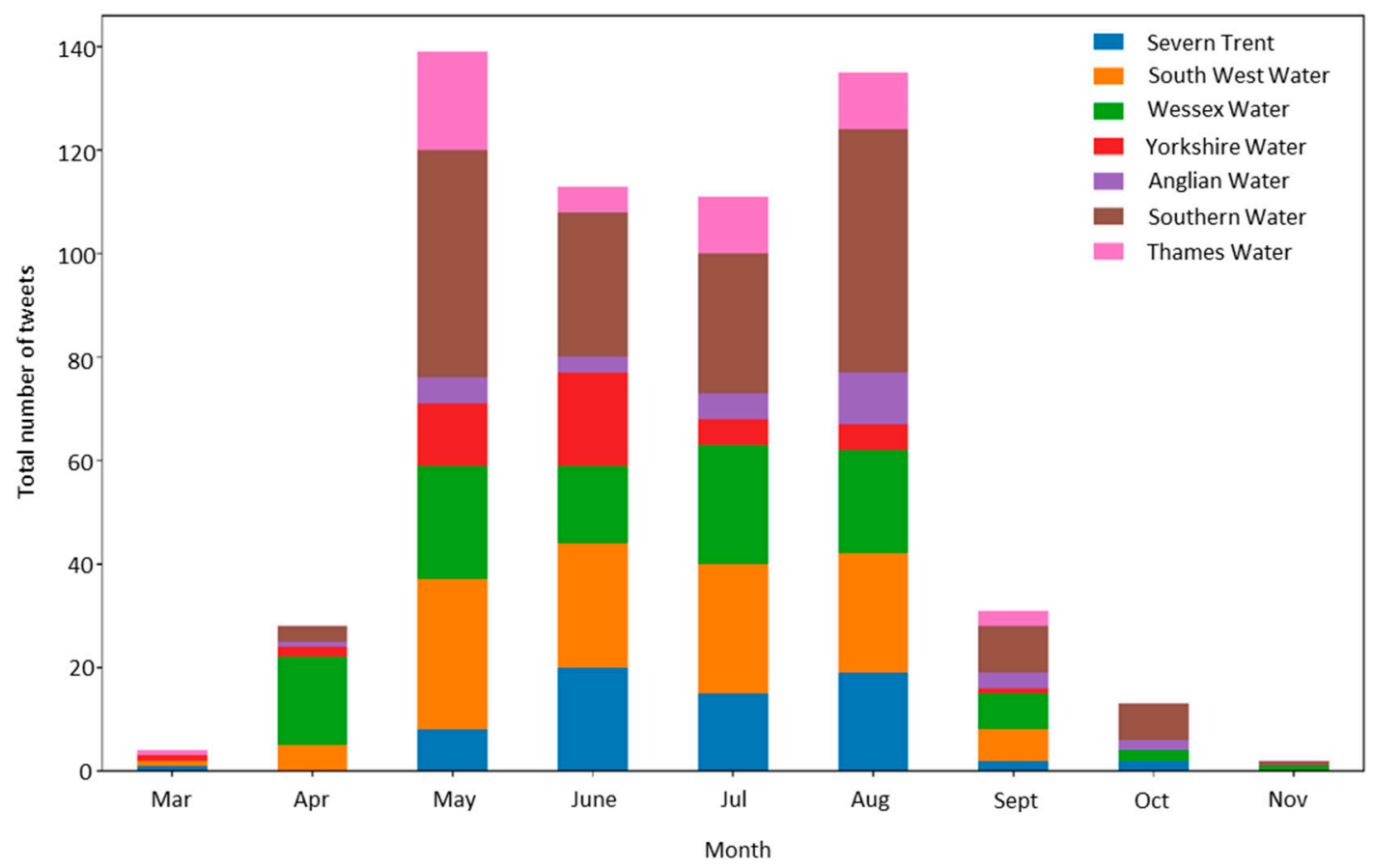

Figure 1. Total number of Twitter posts and retweeted messages about water saving by seven WSPs between 16/03/2020$05 / 11 / 2020$. 
Table 2. Twitter messages from UK WSPs relating to weather and water availability in 2020.

\begin{tabular}{|c|c|}
\hline Ref & Twitter Post \\
\hline Tw-1 & $\begin{array}{c}\text { 'We will of course continue looking after your water, making sure your water and waste services run as you're used to. } \\
\text { These are challenging and unprecedented times, but we take our responsibility to look after one of life's essentials } \\
\text { seriously, and we'll do just that.' }\end{array}$ \\
\hline Tw-2 & $\begin{array}{l}\text { "Did you know our reservoirs can store a total of 10,323.25 million litres? While the sunshine has been in full force } \\
\text { during spring, rainfall has been below average and with the warmer summer months on their way, now is the time to } \\
\text { help \#SaveEveryDropDroplet \#WaterSavingWeek" }\end{array}$ \\
\hline Tw-3 & $\begin{array}{c}\text { "Alex has been working round the clock, making sure tankers are able to get around our region to keep water flowing. } \\
\text { There's water in our reservoirs, the challenge is to get it to homes quick enough as water is being used faster than we } \\
\text { can treat it. Please use water wisely." }\end{array}$ \\
\hline Tw-4 & 'We've seen a big increase in water demand-in fact, some days we've been pumping an extra 140 million litres of water!' \\
\hline Tw-5 & $\begin{array}{l}\text { 'Lockdown has been causing high demand for water and in hot weather people are using even more and it's a challenge } \\
\text { for us to keep pressure up. Please be a \#water hero and use no more than you need to.' }\end{array}$ \\
\hline Tw-6 & $\begin{array}{c}\text { "After the driest May ever on record \& } 266 \text { hours of sunshine, it's no surprise that \#Yorkshire's reservoirs sit } 9 \% \text { lower } \\
\text { than this time last year. Read our FAQs about \#watersaving." }\end{array}$ \\
\hline
\end{tabular}

While there were no mentions of drought on Twitter or within the survey, one WSP mentioned the possibility of a temporary use ban being imposed (Table 1, Int-9) during this period. In South East England, a location known to be a 'water stressed' region [28, $29,56]$ Southern Water were issuing daily Twitter messages over the period 22/05/2020 $30 / 05 / 2020$ encouraging customers to save water to help reduce demand (Table 2, Tw-6). South West Water and Wessex Water were also actively encouraging customers to save water with general tips and advice.

Not all of the WSPs experienced demand issues at the same time. One WSP discussed how the hot summer heatwave during August resulted in an increase in demand. The easing of the lockdown during the summer of 2020 created a different set of challenges for some WSPs in response to a sudden influx of tourists into the region and the reopening of local businesses (Table 1, Int-10). For one WSP, a lockdown over the summer forcing people to 'staycation' was also a concern because this would place too much demand on local water resources.

WSPs discussed the challenges of managing 'spikey' and unpredictable demands with regard to water demand. One WSP explained how their ability to cope 'was a function of the ability to supply' and this was achieved by ensuring there was enough storage capacity within the network to manage the increase in demand and bring the treatment works up to capacity. They also engaged customers in demand management within one local area by encouraging them to think about how much water they used for daily activities. This resulted in a $4 \%$ reduction in demand.

As well as managing water demand, WSPs spoke about the panic buying of toilet paper at the start of the first national lockdown. This resulted in an increase in blockages throughout the wastewater network as a result of flushing items other than toilet paper down the toilet. One WSP explained how the dry conditions had resulted in reduced velocity of flow making it more difficult to flush the blockages through the system.

The use of WRMPs was also discussed within the context of achieving resilience within the water sector to future long-term challenges of climate change and managing short term shocks to the system such as the pandemic and weather related hazards. For many WSPs, these plans are extremely useful to justify investment for the future but are not agile enough to cope with short term shocks with regard to water availability and the ability to develop appropriate solutions in response to 'peaky demands'.

\subsection{Were There Regional Differences in Water Availability?}

Throughout spring 2020, all regions within England experienced below average rainfall (Figures 2 and 3), with the lowest rainfall recorded in the East of England during 
March and North East England during April [57-61]. The standardised precipitation index map (Figure 2 shows each region experienced dry conditions over the 3 month period [38], with East and Central England experiencing 'severely dry' and 'exceptionally dry' conditions.

During April, monthly mean river flows were 'below normal' in parts of the North East, North West and South West of England with exceptionally low reservoir storage levels reported in the north-east of England [58]. As the dry weather persisted throughout May, monthly mean river flows were recorded as 'exceptionally low' in the South West (Figure 2) and reservoir storage levels in the North of England were recorded as 'below normal', 'notably low' and 'exceptionally low' at 30\% of the reservoirs monitored by the Environment Agency [59]. May was recorded as the driest on record [62] and the prolonged period of dry conditions resulted in a meteorological drought during the spring 2020 [63].

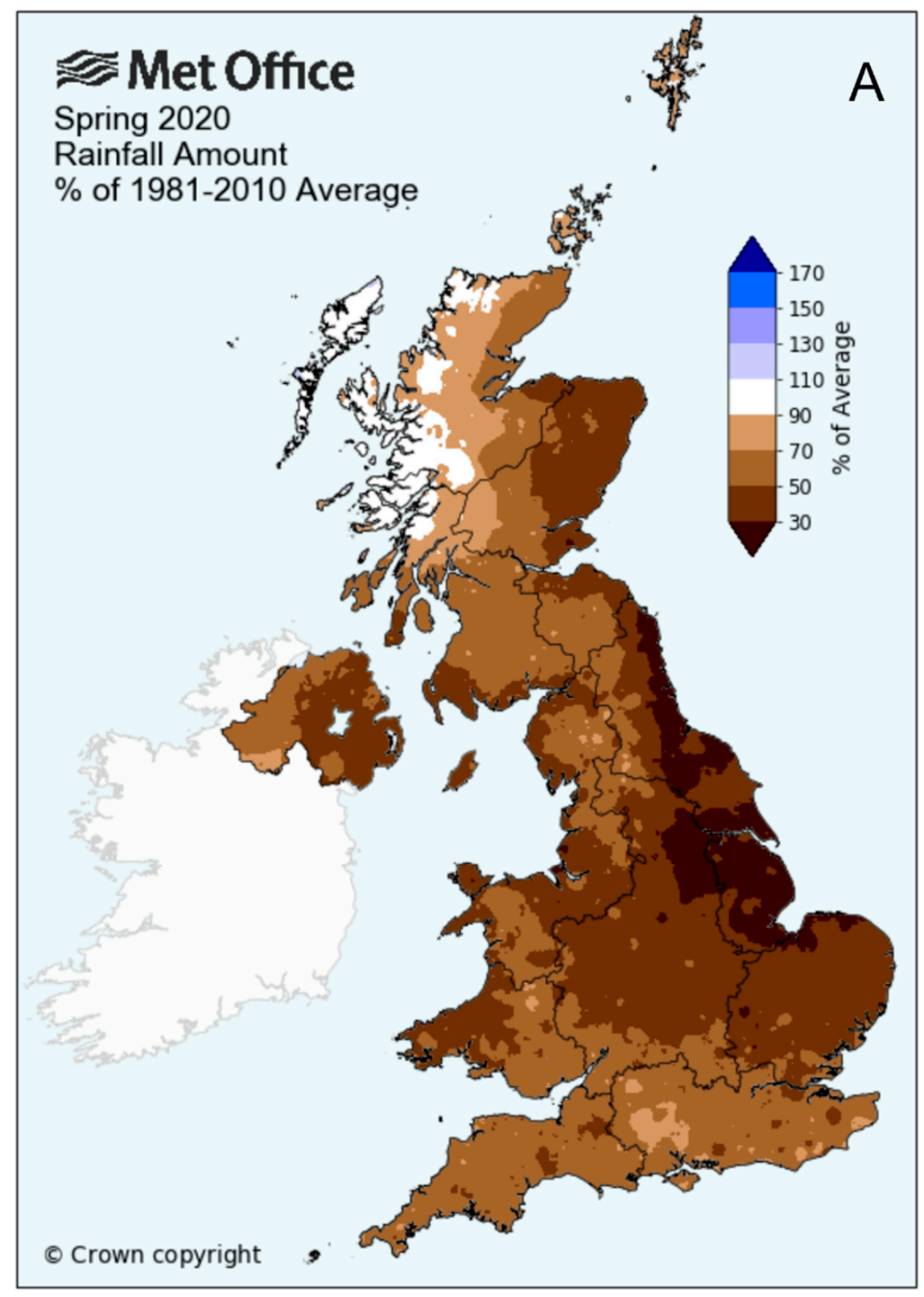

Figure 2. Cont. 


\begin{tabular}{|l}
\hline River flows \\
$\qquad$\begin{tabular}{|l|}
\hline Exceptionally high \\
Notably high \\
Above normal \\
Normal \\
$\bigcirc_{\text {Below normal }}$ \\
$\bigcirc_{\text {Notably low }}$ \\
$\bigcirc_{\text {Exceptionally low }}$ \\
$\bigcirc_{\text {No data }}$ \\
$5 \%$ of long term average \\
\hline
\end{tabular}
\end{tabular}
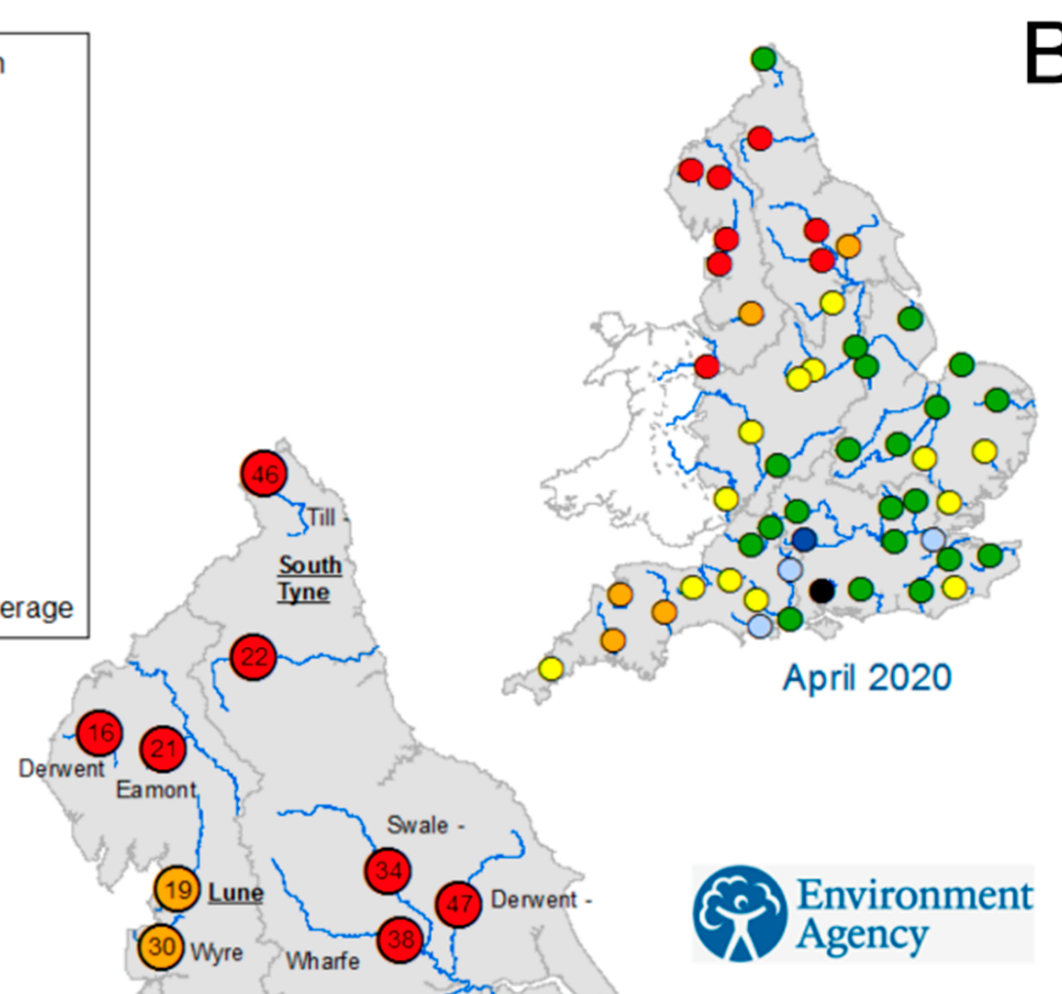

April 2020
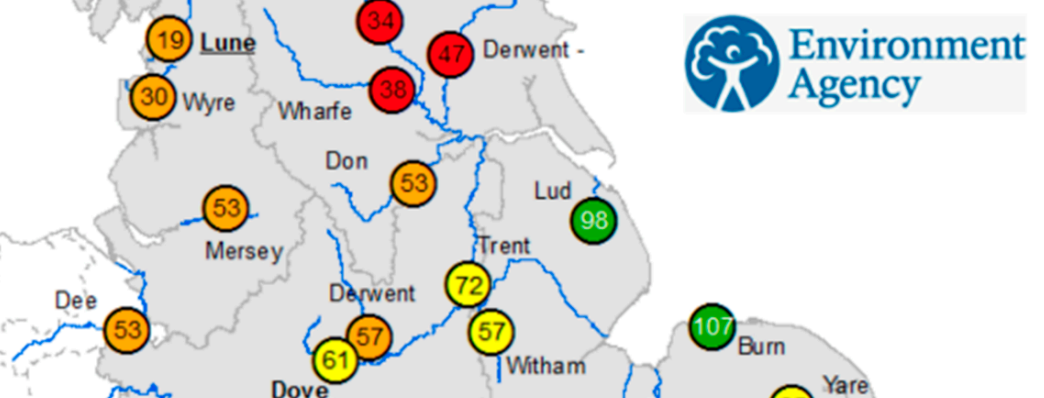

\section{(10)}

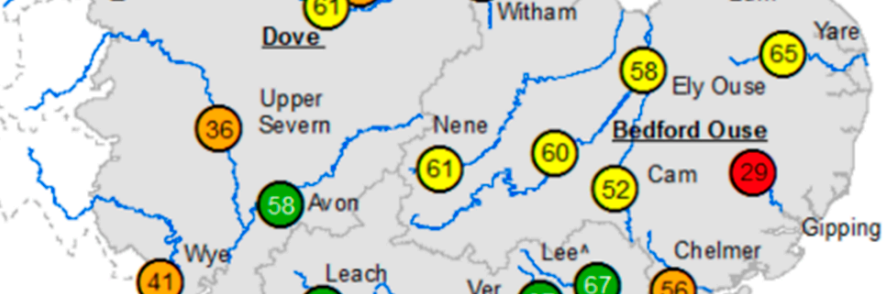

Leen Chelmer

Ver 8767 (56)
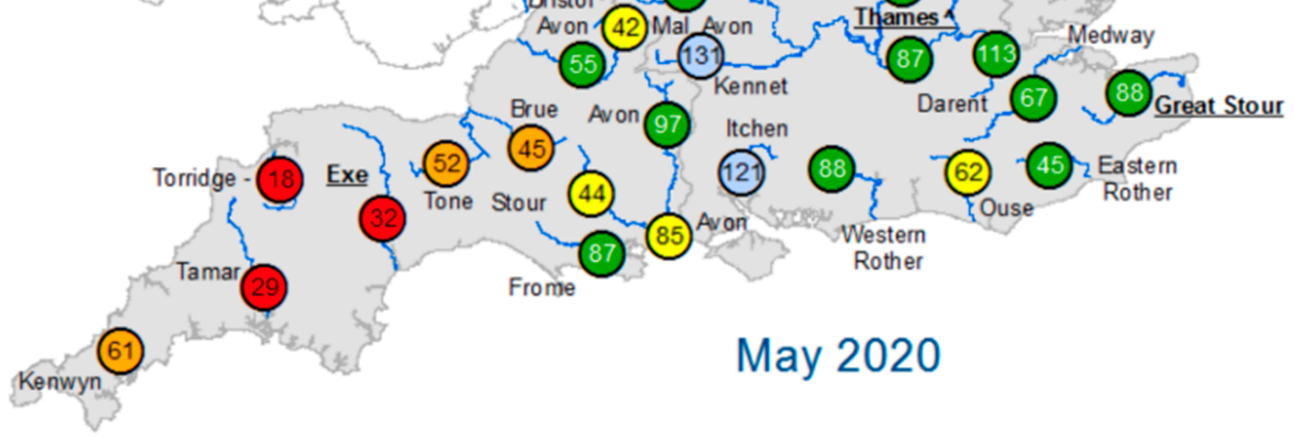

Figure 2. Cont. 


\section{SPI Areas}

Extremely dry (SPI below -2.0)

Severely dry (SPI from -2.0 to -1.5 )

Moderately dry (SPI from -1.5 to -1.0 )

Mildly dry (SPI from -1.0 to 0.0 )

Mildly wet (SPI from 0.0 to 1.0 )

Moderately wet (SPI from 1.0 to 1.5 )

Severely wet (SPI from 1.5 to 2.0 )

Extremely wet (SPI above 2.0)

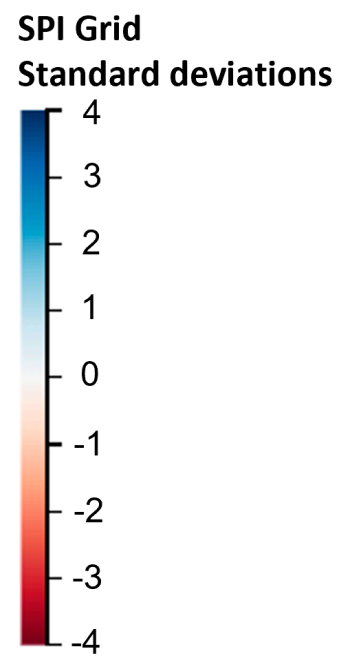

Figure 2. A: Spring 2020 Rainfall Amount, \% of 19822010 Average (Source: Met Office, 2020. Licenced under the Open Government Licence) [64]. B: River flows for May 2020. (Source: Environment Agency, 2020. Crown copyright. All rights reserved. Environment Agency, 100024198, 2020). C: Standardised precipitation index over a three-month period for May 2020 using the drought tool from CEH Wallingford [38], (@ Database Right/Copyright NERC-Centre for Ecology \& Hydrology. All rights reserved. Contains material based on Met Éireann data ( $)$ Met Éireann and Met Office data () Crown copyright).

Figure 3 shows the regional variations in monthly total rainfall and mean temperature from 2017 to 2020. This covers the period leading up to the 2018 drought, experienced within many parts of the UK $[65,66]$. Below average rainfall totals during early 2017 in South, East and Central England followed by a dry autumn and an exceptionally dry May to July 2018 resulted in a widespread meteorological drought during 2018. River flows in the North and West of England were low and reservoir storage was 1\% higher than levels recorded during the 1995 drought [65]. This prolonged dry period throughout 2017 to 2018 resulted in an agricultural drought being declared in many parts of England [65]. 
Water resource stress in the North West of England resulted in United Utilities preparing to impose a hosepipe ban. However, a period of rainfall followed, and the hosepipe ban was not declared.

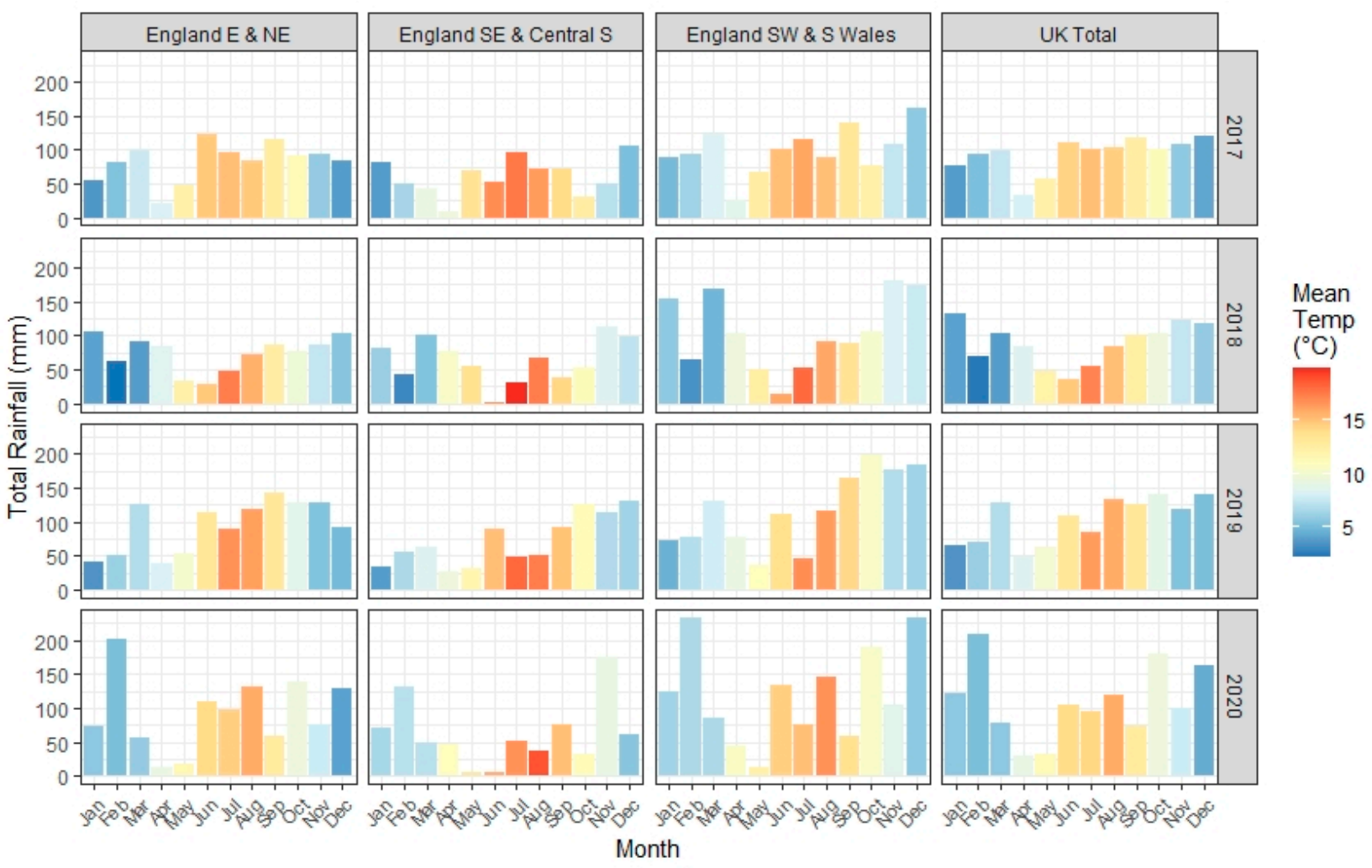

Figure 3. Total monthly rainfall $(\mathrm{mm})$ and mean temperature $\left({ }^{\circ} \mathrm{C}\right)$ for (Left-Right) East and North East England, South East and Central South England, South West England and Wales, and the whole of the UK for 2017-2020, (Contains material based on Met Office Data. Source: Met Office, 2020. Licenced under the Open Government Licence), [64].

The extremely wet winter of $2019[67,68]$ had resulted in the replenishment of groundwater aquifers, rivers and reservoirs. However, the low rainfall from March to May 2020, was a cause for concern; particularly in the East and South East of England that had experienced the impact of the 2018 drought [69]. During June 2020 the National Drought Group was convened to assess the combined impact of the prolonged period of dry weather and lockdown on water resources within the UK. WSPs were advised to take action to encourage customers to use less water and use water wisely. This was reflected in the increase in Twitter messages throughout June 2020 (Figure 1). In July 2020, the group re-convened to assess the situation following the rainfall experienced throughout June. It was concluded that the rainfall had alleviated the threat of drought [70]. However, WSPs were continuing to encourage their customers to use water wisely. This was accompanied by a public awareness campaign by Waterwise conducted on social media and Twitter and was reflected in the increase in Twitter messages throughout July to August 2020 (Figure 1). The challenges of a nationally imposed lockdown with everyone at home enjoying the hot dry weather and the resultant surge in water demand forced WSPs to acknowledge the influence of customer behaviour on water demand.

Within the semi-structured interviews WSPs commented on how customer behaviour strongly influenced water demand and how this was connected to public perception of the social value of water. One WSP discussed the lack of consideration regarding the use of drinking water to flush toilets or the water treatment process (Table 3, Int-11). WSPs discussed viewing social media posts of people regularly filling and emptying hot tubs or using sprinklers to water the garden and entertain children, suggesting there was a lack of understanding about where water comes from, how it is treated and transported 
to their homes. WSPs commented on the need to change customer attitudes, perceptions and behaviour surrounding water usage in order to manage long term challenges to water resources in England and Wales (Table 3, Int-12).

There was a comment that the public has become indifferent to water, because it is a basic human right (Table 3, Int-13). The ability to turn on a tap and have an instant supply of water has contributed to the public perception that water is an infinite resource. WSPs were concerned by the lack of awareness around the future availability of water, because a lack of access to water is not something that many people had experienced (Table 3, Int-14). WSPs highlighted this perception was also driven by the low cost of water and social attitudes that do not reflect the current or future situation with regard to the availability of water resources (Table 3, Int-15).

Table 3. Reflections on customer attitudes and perceptions to water availability, taken from semi-structured interviews conducted by Lawson et al. (2021).

\begin{tabular}{cc} 
Ref & Qualitative Explanation \\
\hline Int-11 & '... there is a real lack of value associated with water ... with people happy to pour drinking water quality on the \\
garden or flush the toilet with it'
\end{tabular}

\subsection{What Can We Learn from an Acute Threat, Such as COVID-19, to Better Prepare for Chronic Threats?}

The Department for the Environment, Food and Rural Affairs (Defra), determines the regulatory framework and policy for water in England. WSPs are expected to deliver resilient water supplies as documented within a WRMP. These are submitted every 5 years and detail the forecast supply and demand within each WRZ and how the WSP will secure the availability of public water supplies. WSPs are also required to submit water resource market information. This comprises data tables for each WRZ detailing the baseline supply demand balance, the forecast supply demand balance and the zone deficit. The WRMPs and the water resources market information submitted by the WSPs to the water regulatory authority Ofwat for 2019 were analysed to understand the current situation regarding water availability in the UK and the forecast for the next 25 years. The supply demand deficit was calculated for each WRZ for the period 2020 to 2045 (Figure 4).

Almost a third (30\%) of the WRZs in the East and South East of England are already in deficit with $54 \%$ expected to be in deficit within the next 5 years (Figure 4 ). These areas are classified as 'serious' with regard to water stress [71-73]. The East of England is categorized as one of the driest parts of the country receiving on average, less than $700 \mathrm{~mm}$ of rainfall per year [74]. Water resources within the South East rely on winter rainfall to recharge chalk aquifers and reservoirs and are vulnerable to periods of high water demand during the summer following a winter of below average rainfall [75]. This region also has the highest annual average sunshine duration in the country [75]. Both regions have a high agricultural demand for water resources [76-79] and an increasing population [28,29,44,45]. 


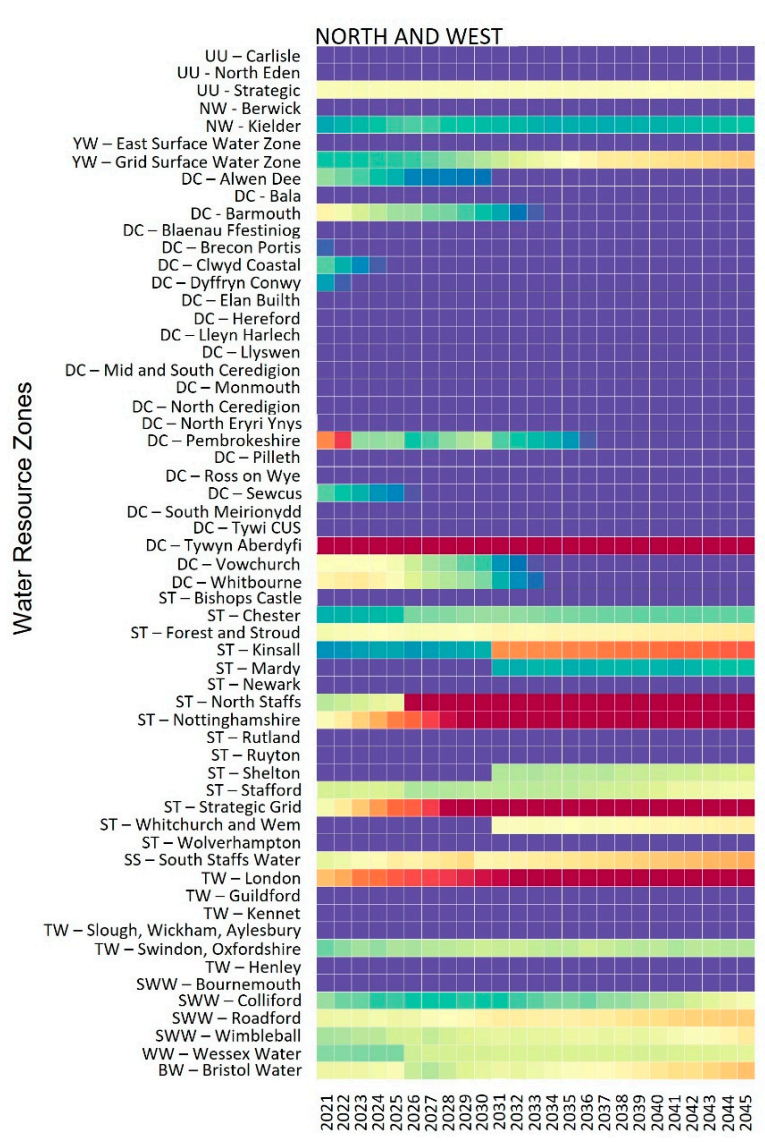

Legend.

$\begin{array}{llcl}\text { AF } & \text { Affinity Water } & \text { ST } & \text { Severn Trent Water } \\ \text { AW } & \text { Anglian Water } & \text { SW } & \text { Southern Water } \\ \text { BW } & \text { Bristol Water } & \text { SS } & \text { South Staff Water } \\ \text { CW } & \text { Cambridge Water } & \text { SWW } & \text { South West Water } \\ \text { DC } & \text { Dwr Cymru Welsh Water } & \text { TW } & \text { Thames Water } \\ \text { ESW } & \text { Essex and Suffolk Water } & \text { UU } & \text { United Utilities } \\ \text { NW } & \text { Northumbrian Water } & \text { WW } & \text { Wessex Water } \\ \text { PW } & \text { Portsmouth Water } & \text { YW } & \text { Yorkshire Water } \\ \text { SES } & \text { SES Water } & & \end{array}$

Figure 4. Water resource zones (WRZ) supply and demand deficit heatmap for the period 2020-2025 for WSP's in England and Wales.

The heatmap (Figure 4) highlights the vulnerability of these WRZs to water availability and future water demand. This was also reflected in the survey response [3]. There were 15 references to water "demand" within the survey with the majority of participants from the South East region (60\%) and currently working for a water service provider (67\%). Within the semi-structured interviews [4] participants from the South East also commented how the sudden change to water resources and the increase in demand was difficult to forecast throughout the pandemic. However, participants from other regions of the country stated that demand went down. This was also reflected within the social media response. Southern Water consistently tweeted throughout the summer of 2020 (Figure 1, Table 2, Tw-4) requesting that customers reduce their water consumption so they could manage the increase in demand throughout the network. 
In the North, West and Central areas of England 10\% of the WRZs will experience a deficit within the next 5 years. All of the WSPs have mutual aid agreements to support one another during immediate periods of difficulty and the potential for water trading is discussed within their WRMPs. However, this is explored within the context of a long term 25-year forecast with a singular focus on the impact of 'design droughts' and 'dry weather average demand.' As discussed within Sections 1 and 2, the immediate threat of a pandemic and a prolonged period of hot dry weather increased water demand in many parts of the country. While a drought was not declared, WSPs in areas of the country not categorised as 'water stressed' discussed the challenge of keeping up with demand. The immediate impact of multiple stressors on the system highlighted a potential vulnerability regarding water resource management. A singular focus on 'design droughts' and 'dry weather average demand' is not sufficient to manage the combined impact of immediate threats and long-term challenges.

The potential for water trading was explored within WRMPs as part of a long-term strategic approach toward securing resilient water supplies. While the importance of water trading was highlighted by many of the WSPs, the WRMPs discussed exploring options rather than having agreements in place. This has also been widely advocated as a potential option in the management of future water resources within England [28,29,80,81].

Water trading was discussed in the semi-structured interviews in the context of both long-term planning and as an immediate response to the pandemic. WSPs discussed the high operational costs associated with the transportation and pumping of water from one region to another (Table 4, WT-1, WT-2) and how the public perception was that water could be moved relatively easily between locations. WSPs explained the complexities relating to the introduction of invasive species (Table 4, WT-3) and the environmental impact of building and installing pipework for water transportation (Table 4, WT-2). They also discussed a lack of commitment from the regulator Ofwat as to whether these schemes should be adopted, and the timescales involved in delivering 'large costly infrastructure' schemes (Table 4, WT-4, WT-5). All the discussions highlighted the complexity of water transfer and how this was a long-term consideration rather than an option that could have been implemented during the pandemic.

Table 4. Discussions relating to water trading, taken from semi-structured interviews conducted by Lawson et al. (2021).

\begin{tabular}{|c|c|}
\hline Ref & Qualitative Explanation \\
\hline WT-1 & $\begin{array}{c}\text { '... whenever you speak to people about water resources they say oh well there's plenty of water in [location] why } \\
\text { don't you just use that. But it's not that easy. It really isn't that easy ... water is really heavy, and the cost of moving it } \\
\text { is massive.' }\end{array}$ \\
\hline WT-2 & $\begin{array}{l}\text { 'Yeah literally it would cost billions, those schemes to build the pipe work then cost millions each day to actually run it } \\
\ldots \text { and then you've got the environmental impacts of that, that you could have to balance off. So, I think there are so } \\
\text { many options really before you get to that.' }\end{array}$ \\
\hline WT-3 & $\begin{array}{l}\text { '... if you are bringing water from a long way away from a different region, if it's raw water then there are lots of } \\
\text { concerns over invasive species and environmental concerns about bringing different types of water in.' }\end{array}$ \\
\hline WT-4 & $\begin{array}{l}\text { 'Ofwat are kind of on the fence about it. They want it to happen, but they don't want to fund it, so I think there is a bit } \\
\text { of a dynamic there ... but I think it's just getting everyone around the table and saying are we actually going to crack } \\
\text { on with this or not.' }\end{array}$ \\
\hline WT-5 & $\begin{array}{c}\text {... but the speed that those things move and when you are talking about some of these schemes they are costly } \\
\text { infrastructure schemes so there are a lot of hoops to jump through before you actually end up delivering something that } \\
\text { gives you that wider resilience... }\end{array}$ \\
\hline
\end{tabular}

\subsection{How Can We Increase Resilience to the Acute and Chronic Threats Our Water Resources Face?}

During February 2021, the Environment Agency initiated a consultation on water stress recharacterization of England [50]. Central, Southern and Eastern parts of England have been classified as being in 'serious' water stress within the previous two consultations [71,72]. The 2019 Water Resource Management Plans and the National Framework for 
Water Resources were used to inform the development of the 2021 consultation framework. While over $50 \%$ of UK households in England have a water meter fitted [82] the intention is to increase this and assess the option of compulsory water metering in water stressed locations. The consultation is seeking to determine resilience and sustainability with regard to the provision of water resources for both public and environmental benefit. However, it is focused on the long-term challenges associated with an increasing population and climate change. If $54 \%$ of WRZs in the East and South East are likely to be in water supply deficit in 5 years' time, many of these challenges require immediate attention rather than a singular focus on the long-term planning for drought.

Events such as the 'Beast from the East' and the COVID-19 pandemic have demonstrated the need to take a holistic approach regarding the provision of resilient water supplies within England and Wales. This needs to be contextualised within a strategic response framework that can cope with acute multiple stressors and the long-term challenges of climate change, an increasing population, an aging water infrastructure network and the protection of the environment.

The vision to ensure the long-term resilience of water supplies within England and Wales to drought $[28,29]$ recommended a 'twin track' approach to reduce demand through compulsory metering and leakage reduction and increased investment to improve future water supply infrastructure, and the development of a national water transfer network. It was proposed that actions to deliver the approach would be supported through the development of a regulatory framework and as part of the 2019 review of water prices, conducted by the water regulator Ofwat. However, a review conducted by the National Audit Office [80] and the UK Parliament, Public Accounts Committee severely [81] criticised Defra, Ofwat and the Environment Agency for 'taking their eye off the ball' and not taking immediate action to ensure the resilience of water supplies now and in the future. The report highlighted how relatively little progress had been made over the last 20 years to reduce the amount of water lost through leakage and how more needs to be done to balance infrastructure investment and customer bills. This was also discussed within the context of the semi-structured interviews with one WSP explaining the difficulties of using WRMPs to justify infrastructure investment for situations like those experienced during the 'Beast from the East' event and the COVID-19 pandemic. For some WSPs, it was not about having enough water resources at a regional level, it was about not being able to manage localised issues relating to peaky and unpredictable demand. While WRMPs were considered to be important to understand long term challenges regarding water resources, they were not perceived to be agile or detailed enough to enable WSP to effectively manage short term acute threats.

In March 2020, the Environment Agency published a policy paper to develop a national framework for water resources in England and to support the UK Government's 25-year environmental plan [82]. Even though WSPs produce WRMPs every five years, these alone, were not considered sufficient in order to develop a strategic approach to national water resource planning for the future. A national approach through the development of regional consortiums was proposed to overcome WSP company barriers and encourage a multiorganisational approach to bring water companies together to identify future challenges and find solutions. This includes the development of 'multi sectoral regional resilience plans' to address the water resource challenges WSPs will face as a result of drought, the future challenge of climate change, increasing population and urban development $[79,82]$. However, there have been numerous reports highlighting the challenges that WSPs will face with regard to the future availability of water resources, including Water UK [28] Water resources long term planning framework (2015-2065), the National Infrastructure Commission [29], Preparing for a Drier Future, Environment Agency [71,72,77] and the WSPs' WRMPs [44-53]. Despite some of the recommendations, such as leakage reduction and water trading being explored within the WRMPs, this has not delivered the change that is required to secure the future resilience of water supplies. Many recommendations are 
considered within the context of the single long-term threat of drought and not within the context of a drought occurring in combination with, or at the same time as other stressors.

It is understandable that there is a strong focus on the impact of drought on water resources within England and Wales, particularly with regard to water stress locations such as the East and South East of England and the future impact of climate change within these regions. However, as demonstrated throughout the COVID-19 pandemic, the 'Beast from the East' and the flooding of Mythe water treatment works during 2007, there are other weather-related challenges that may also threaten the resilience of water supplies within England and Wales. Within the semi-structured interviews, all of the WSPs discussed the main threats and hazards to the water sector. These included, Foot and Mouth, Swine Flu, Influenza, Cyber threats, and Brexit. However, these were all discussed within the context of single threats and hazards as defined within the company risk register. Contingency planning was not discussed within the context of multiple threats and hazards occurring at the same time. This was also observed throughout the review of WRMPs, there was a strong focus on preparing for the single threat of a 'design drought' with only 6 WSPs considering water resources within the context of other hazards. Again, these were considered as single threats and not as multiple stressors despite the recommendations within the water resources planning guidelines [56] and the guiding principles for water resource planning $[53,83]$ to assess the resilience of water supply systems to events other than drought, such as freeze-thaw or flooding. Even within the national risk register, drought is considered within the context of historical design droughts and as a singular event [84].

WSPs were also criticised for not engaging with customers to reduce water demand. The National Audit Office stated that there was no evidence to suggest that public awareness activities had contributed to a change in customer behaviour with regard to reducing water demand [80]. There was also strong criticism of the UK Government for failing to initiate a national communication strategy to encourage customers to use water more efficiently [81]. Many of the WSPs discussed the influence of customer behaviour on water demand throughout the COVID-19 pandemic and how customer behaviour was strongly associated with attitudes and perceptions regarding the social value of water. This was largely attributed to customer expectation that water is readily available from the tap and they don't need to worry about it not being available. Previously, WSPs considered this to be a positive reflection of the service they provided, and this customer perception was something to be valued. However, with many parts of the country experiencing potential supply demand deficit in the coming years, WSPs have recognised the need to ensure their customers are properly informed regarding the availability of water resources now and in the future. This demonstrates a shift in attitude, with WSPs recognising the need to engage customers in the management of water resources within England and Wales.

However, this also requires a greater understanding of the challenges that WSPs face now and in the future. One WSP explained how many people don't understand the functionality of raw water storage and the limitations regarding reservoir capacity. There is a perception that because it has rained there must be a plentiful supply of water available for use because there is a limitless amount that can be stored within the reservoirs. WSPs also talked about raising customer bills to encourage a greater understanding of the value of water. However, there are challenges with this approach because it conflicts with the regulators who want to keep customer bills as low as possible. This was also reflected within the UK Parliamentary Select Committee report [81] with the water regulator, Ofwat criticised for not allowing WSPs to increase customer bills in locations where customers had been supportive of this approach.

WSPs provided many different perspectives regarding how resilience within the water sector could be achieved. This included increased water trading between water companies through network connectivity, strategic storage and the increased deployment of domestic smart meters. These can be used to provide accurate information regarding demand patterns. 
Many WSPs have initiated campaigns to increase public awareness of water resources and to try and engage customers to use water more efficiently, such as Anglian Water's, 'Love Every Drop' campaign and Southern Water's, 'Water for Life'. Water UK also launched a national campaign in 2019 called 'Love Water' with the aim to raise awareness of the importance of water. Regular campaigns are also run by Waterwise, an independent organisation promoting water efficiency within the UK. Throughout the pandemic many of the WSPs developed innovative methods to try and encourage customers to use less water. These included the WSP pledging to donate money to charity if customers saved water, water butt competitions and water-saving challenges. All of these activities were aimed toward engaging customers to understand the value and importance of water as a precious resource, while simultaneously encouraging water efficiency to help WSPs manage increased customer demand. Encouraging public participation and engagement is an effective strategy to influence long term behavioural change, empowering customers to work together with WSPs to drive forward positive change for the future [85].

This research focused on the challenges relating to multiple stressors and water resource management in England and Wales. Given the COVID-19 pandemic was a global disruption, other countries experienced similar challenges. The increase in water demand combined with prolonged periods of hot dry weather and drought were also experienced in other European countries [2]. Research conducted in Germany, Italy and Ireland also highlighted an increase in water demand throughout the period of the first national lockdown $[2,7,9]$. A change in diurnal demand patterns and a geographical shift in demand from cities to residential areas was also observed and attributed to a lack of commuting and an increase in people working from home [7,9]. This raised concerns regarding the longevity of behavioural changes and the impact on the future availability of water resources and the water distribution system [9] especially if working from home persists and there is a continual increase in water intensive practices $[7,9,86]$.

There was a 9 to $13 \%$ increase in domestic water demand across England and Wales from February to October 2020 [14,15]. This covered the period of the first national lockdown (23/3/2020-10/05/2020) and the summer of 2020 when restrictions were lifted. The largest increase in water demand was in the South West and the South of England [14]. The lowest increase in water demand was in the North [14]. Within residential areas, WSPs observed a change in peak demand patterns and total water consumption. An evening peak in water demand was dominant and attributed to greater flexibility of normal daily routines as a result of people working from home [14,15]. This also provided people with the opportunity to spend more time gardening and enjoy the prolonged period of hot, dry weather through water related activities such as paddling pools and hot tubs [15]. In contrast the Central Business Districts (CBD) experienced a decrease in water consumption with commuters now working from home. This created challenges with sewage treatment works suddenly forced to operate under capacity.

The results of these studies highlight the complex interrelationships between water availability, water demand patterns and the influence of other stressors on the ability to determine accurate forecasts for future water resource management planning [2,37]. However, despite the importance of ensuring sustainable water resources and water availability for the future, there is a lack of policy intervention measures within European countries that focus on the ability of the water sector to cope with potential stressors in the future [2]. A greater understanding of domestic and non-domestic water demand between the CBD, urban residential and rural residential locations will help to inform future water resource and management strategies, the development of effective policy intervention measures and the ability to manage the combined impact of immediate threats and long-term challenges through effective risk management strategies. 


\section{Conclusions}

Our findings support the following conclusions:

Water demand increased but was unpredictable and hard to forecast. All WSPs reported an increase in domestic demand, and a change in peak demand and diurnal flow patterns in response to changing customer behaviour during spring 2020.

Weather conditions exacerbated the challenges faced in spring 2020. England experienced below average rainfall in spring 2020. The extremely wet winter of 2019 replenished ground and surface waters, but the low spring rainfall was a cause for concern, particularly in parts of the country that experienced the 2018 drought. Monthly mean river flows were 'below normal', with 'exceptionally low' reservoir storage levels in parts of England. May 2020 was the driest on record, resulting in a meteorological drought in Spring 2020.

Customer behaviour strongly influenced water demand during the lockdown. Social media platforms were used to inform customers on how to save water. As demand for water increased, Twitter messages became more direct, highlighting how the additional demand had created difficulties for WSPs. There is a need to influence customer attitudes, perceptions and behaviour around water use to manage long term challenges on the availability of water resources.

WSPs struggled to keep up with demand irrespective of WRZ deficits. More than half (54\%) of the WRZs in the East and South East of England are expected to be in deficit in the next 5 years. A much lower proportion of WRZs (10\%) in North, West and Central England are likely to be in deficit in the same period. While a drought was not declared in 2020, many WSPs struggled to keep up with demand. The immediate impact of multiple stressors on the system highlighted a potential vulnerability which is not covered by the current process for managing risk.

Learning from acute threats can help to increase system resilience to chronic threats. Short-term events such as the 'Beast from the East' and the COVID-19 pandemic have demonstrated the need to take a holistic approach to the provision of resilient water supplies. This needs to be contextualised within a strategic response framework that can cope with acute multiple stressors, weather conditions and the long-term challenges of climate change, an increasing population, an aging water infrastructure network and the protection of the environment.

Multi-sectoral regional resilience plans, which consider multiple threats occurring simultaneously, are necessary to deliver the change required to secure resilient water supplies. WRMPs are extremely useful to justify future investment, but they are not agile enough to cope with short term shocks to water availability or to support the development of appropriate solutions to 'peaky demands'. A national approach, involving regional consortiums and the development of 'multi-sectoral regional resilience plans' may be required. There is a strong, understandable, focus on the impact of drought on water resources within England and Wales, particularly in water-stressed locations. However, there are many other challenges which, whilst recognised, are often discussed within the context of single threats and hazards as defined within the company risk register. A singular focus on 'design droughts' and 'dry weather average demand' is not sufficient to manage the combined impact of immediate threats and long-term challenges.

\section{Recommendations}

Applying the traditional risk management approach with a singular focus on specific threats and hazards is no longer sufficient to develop resilient and sustainable strategies for water resources management and events arising from acute and chronic stressors. There needs to be a shift away from the traditional risk management approach to plan and prepare for water resource availability towards a resilient based strategy. An alternative approach such as the Safe and SuRe framework [12] could be applied. This framework recognises that it is impossible to identify every threat to the system, the resultant impact or the socio-technical consequences. Instead, this approach focuses on system failure modes, 
their impact and consequences and provides the opportunity to identify interventions to improve overall system resilience [4,12].

The review of WRMPs highlighted that WSPs are still exploring options with regard to water trading, rather than securing agreements. Significant barriers remain: the high operational cost of transporting and pumping water from one region to another, the complexities relating to the introduction of invasive species, the environmental impact of building and installing pipework, the lack of regulatory commitment on whether these schemes should be adopted, and the timescales involved in delivering 'large costly infrastructure' schemes. Water transfer is a long-term consideration rather than an option that could have been implemented during the pandemic. However, with $54 \%$ of WRZs in the east and southeast expected to be in deficit within the next five years, options regarding water trading between WSPs need to be seriously explored as viable options.

Initiatives outlined in WRMPs support consumption reductions in line with the National Infrastructure Commission [29] recommendation of 118L/person/day by 2050, from the current 142 litres/person/day baseline [87]. However, by this point, 70\% of WRZs in the East and South East are likely to be in deficit (and more than $20 \%$ in the North, West and Central England) (Figure 4). As we transition out of restrictions postpandemic, understanding patterns of where people spend their time, and the impact this has on domestic water use, will be crucial. Possible future scenarios, which account for an increase in working from home, dispersal from cities and a significant uptake in online and virtual activities are all likely to result in an increase in household demand and increase in PCC [88]. However, the importance of these changes will vary geographically and changes will be more significant at WRZ level [88]. Further reduction (below 118L/person/day) is likely to require intervention beyond the water sector, relying on Government action: national policy changes are much more powerful than actions available to WSPs alone [87]. Therefore, public awareness activities; a national communication strategy; mandatory water labelling; product standards; building regulation changes; and wide-spread smart metering are likely to be necessary to achieve the deep reductions in demand required to offset the massive deficits anticipated in the coming decades. WSPs can conduct public engagement strategies [89] at a local level but this needs to be supported nationally, through policy and regulatory changes [90].

Author Contributions: Conceptualization, S.B., E.L. and S.C.; methodology, S.B., E.L. and S.C.; formal analysis, S.B. and E.L.; data curation, S.B. and E.L.; writing—original draft preparation, S.B., E.L. and S.C.; writing - review and editing, S.C. and D.B.; visualization, S.B. and E.L.; supervision, S.C. and D.B.; funding acquisition, D.B. All authors have read and agreed to the published version of the manuscript.

Funding: Support was available from the UK Engineering \& Physical Sciences Research Council CDT STREAM [EP/L015412/1] to resource E. Lawson's time. The APC was funded by Journal Sustainability as part of a Special Issue on 'Sustainable Water Use'.

Institutional Review Board Statement: Ethical approval was sought and received from the College of Engineering Maths and Physical Sciences (CEMPS) Research Ethics Committee, University of Exeter on 18.05.20 (Ref: eEMPS000265 v3.0).

Informed Consent Statement: Informed consent was obtained from all subjects involved in the study.

Data Availability Statement: Figure 3, contains material based on Met Office Data. Source: Met Office, 2020. Licenced under the Open Government Licence [http:/ /www.nationalarchives.gov.uk/ doc/open-government-licence/version/3/].

Acknowledgments: For Figure 2, A: Spring 2020 Rainfall Amount, \% of 1982-2010 Average. Source: Met Office, 2020. Licenced under the Open Government Licence [http:/ /www.nationalarchives.gov. uk/doc/open-government-licence/version/3/]. B: River flows for May 2020. Source: Environment Agency, 2020. Crown copyright. All rights reserved. Environment Agency, 100024198, 2020. C: Standardised precipitation index over a three-month period for May 2020 using the drought tool from CEH Wallingford [53]. Standardised Precipitation Index time series for IHU groups (19612012) [SPI_IHU_groups] data licensed from NERC Centre for Ecology \& Hydrology. Standardised 
Precipitation Index time series for IHU hydrometric areas (1961-2012) [SPI_IHU_HA] data licensed from NERC Centre for Ecology \& Hydrology. Gridded Standardized Precipitation Index (SPI) using gamma distribution with standard period 1961-2010 for Great Britain [SPIgamma61-10] data licensed from NERC Centre for Ecology \& Hydrology. (C) Database Right/Copyright NERC-Centre for Ecology \& Hydrology. All rights reserved. Contains Ordnance Survey data $\odot$ Crown copyright and database right 2014. Contains material based on Met Éireann data (C) Met Éireann and Met Office data (C) Crown copyright.

Conflicts of Interest: The authors declare no conflict of interest.

\section{References}

1. Institute for Government. Timeline of UK Coronavirus lockdowns, March 2020 to March 2021. Available online: https: //www.instituteforgovernment.org.uk/sites/default/files/timeline-lockdown-web.pdf (accessed on 24 May 2021).

2. Antwi, S.H.; Getty, D.; Linnane, S.; Rolston, A. COVID-19 water sector responses in Europe: A scoping review of preliminary governmental interventions. Sci. Total. Environ. 2021, 762, 143068. [CrossRef]

3. Cotterill, S.; Bunney, S.; Lawson, E.; Chisholm, A.; Farmani, R.; Melville-Shreeve, P. COVID-19 and the water sector: Understanding impact, preparedness and resilience in the UK through a sector-wide survey. Water Environ. J. 2020, 34, 715-728. [CrossRef] [PubMed]

4. Lawson, E.; Bunney, S.; Cotterill, S.; Farmani, R.; Melville-Shreeve, P.; Butler, D. COVID-19 and the UK water sector: Exploring organisational responses through a resilience framework. Water Environ. J. 2021. [CrossRef]

5. Medema, G.; Heijnen, L.; Elsinga, G.; Italiaander, R.; Brouwer, A. Presence of SARS-Coronavirus-2 RNA in sewage and correlation with reported COVID-19 prevalence in the early stage of the epidemic in the Netherlands. Environ. Sci. Techno. Lett. 2020, 7, 511-516. [CrossRef]

6. Polo, D.; Quintela-Baluja, M.; Corbishley, A.; Jones, D.L.; Singer, A.C.; Graham, D.W.; Romalde, J.L. Making waves: Wastewaterbased epidemiology for COVID-19_Approaches and challenges for surveillance and prediction. Water Res. 2020, $186,116404$. [CrossRef] [PubMed]

7. Balacco, G.; Totaro, V.; Iacobellis, V.; Manni, A.; Spagnoletta, M.; Piccinni, A.F. Influence of COVID-19 Spread on Water Drinking Demand: The Case of Puglia Region (Southern Italy). Sustainability 2020, 12, 5919. [CrossRef]

8. Kalbusch, A.; Henning, E.; Brikalski, M.P.; de Luca, F.V.; Konrath, A.C. Impact of coronavirus (COVID-19) spread-prevention actions on urban water consumption. Resour. Conserv. Recy. 2020, 163, 105098. [CrossRef] [PubMed]

9. Lüdtke, D.U.; Luetkemeier, R.; Schneemann, M.; Liehr, S. Increase in Daily Household Water Demand during the First Wave of the Covid-19 Pandemic in Germany. Water 2021, 13, 260. [CrossRef]

10. Abu-Bakar, H.; Williams, L.; Hallett, S.H. Quantifying the impact of the COVID-19 lockdown on household water consumption patterns in England. NPJ Clean Water 2021, 4, 13. [CrossRef]

11. Poch, M.; Garrido-Baserba, M.; Corominas, L.; Perelló-Moragues, A.; Monclús, H.; Cermerón-Romero, M.; Melitas, N.C.; Jiang, S.; Rosso, D. When the fourth water and digital revolution encountered COVID-19. Sci. Total. Environ. 2020, 744, 140980. [CrossRef] [PubMed]

12. Butler, D.; Ward, S.; Sweetapple, C.; Astaraie-Imani, M.; Diao, K.; Farmani, R.; Fu, G. Reliable, resilient and sustainable water management: The Safe \& SuRe approach. Glob. Chall. 2016, 1, 63-77.

13. Neal, M.J. COVID-19 and water resources management: Reframing our priorities as a water sector. Water Int. 2020, 45, 435-440. [CrossRef]

14. Alda-Vidal, C.; Smith, R.; Lawson, R.; Browne, A.L. Understanding Changes in Domestic Water Consumption Associated with COVID-19 in England and Wales. Artesia Consulting and University of Manchester. Available online: https://www.research.manchester.ac.uk/portal/files/185015131/Understanding_changes_in_domestic_water_consumption_ associated_with_COVID_19_in_England_and_Wales.pdf (accessed on 30 November 2020).

15. Marshallsay, D. The Effect of the Coronavirus Lockdown on Water Use. Available online: www.artesia-consulting.co.uk/blog/ New $\% 20$ Waterwise $\% 20$ article! $\% 20$ The $\% 20$ effect $\% 20$ of $\% 20$ the $\% 20$ coronavirus $\% 20 l o c k d o w n \% 20$ on $\% 20$ water $\% 20$ use (accessed on 30 November 2020).

16. Aquatech. Case Study: Data links Covid-19 Lockdowns to Consumption Change. Available online: https://www.aquatechtrade. $\mathrm{com} /$ news/utilities/covid-19-lockdowns-impact-water-consumption/ (accessed on 2 July 2021).

17. Ferrier, N.; Emdad Haque, C. Hazards risk assessment methodology for emergency managers: A standardized framework for application. Nat. Hazards. 2003, 28, 271-290. [CrossRef]

18. Smith, K. Environ.mental Hazards: Assessing Risk and Reducing Disaster, 6th ed.; Routledge: London, UK, 2013.

19. Meyer, R.J. Why We Under-Prepare for Hazards. In On Risk and Disaster: Lessons from Hurricane Katrina; Daniels, R.J., Kettl, D.F., Kunreuther, H., Eds.; University of Pennsylvania Press: Philadelphia, PA, USA, 2005; pp. 153-174.

20. Boin, A.; Hart, P. Organising for effective emergency management: Lessons from research. Aust. J. Public Adm. 2010, 69, 357-371. [CrossRef]

21. Paltrinieri, N.; Dechy, N.; Salzano, E.; Wardman, M.; Cozzani, V. Lessons learned from Toulouse and Buncefield disasters: From risk analysis to the identification of atypical scenarios through a better knowledge management. Risk Anal. 2011, 4, 8. [CrossRef] 
22. Huppert, H.E.; Sparks, R.S.J. Extreme natural hazards: Population growth, globalisation and environmental change. Phil. Trans. R. Soc. A 2006, 364, 1875-1888. [CrossRef]

23. McCallum, E.; Heming, J. Hurricane Katrina: An environmental perspective. Phil. Trans. R. Soc. A 2006, 364, 1845. [CrossRef]

24. Comfort, L.; Kilkon, K.; Zagorecki, A. Modelling Fragility in Rapidly Evolving Disaster Response Systems. Available online: http:/ / repositories.cdlib.org/igs/2003-2 (accessed on 2 July 2021).

25. Boin, A.; McConnell, A. Preparing for critical infrastructure breakdowns: The limits of crisis management and the need for resilience. J. Contingencies Crisis Manag. 2007, 15, 50-59. [CrossRef]

26. Crichton, M.T.; Ramsay, C.G.; Kelly, T. Enhancing organisational resilience through emergency planning: Learnings from cross-sectoral lessons. J. Contingencies Crisis Manag. 2009, 17, 24-37. [CrossRef]

27. Linkov, I.; Anklam, E.; Collier, Z.A.; Dimase, D.; Renn, O. Risk-based standards: Integrating top-down and bottom-up approaches. Environ. Syst. Decis. 2014, 34, 134-137. [CrossRef]

28. Water UK. Water Resources Long Term Planning Framework (2015-2065). Available online: https://www.water.org.uk/ publication/water-resources-long-term-planning/ (accessed on 25 May 2021).

29. National Infrastructure Commission. Preparing for a Drier Future. Available online: https://nic.org.uk/app/uploads/NICPreparing-for-a-Drier-Future-26-April-2018.pdf (accessed on 5 May 2021).

30. Hall, J.W.; Mortazavi-Naeini, M.; Borgomeo, E.; Baker, B.; Gavin, H.; Gough, M.; Harou, J.J.; Hunt, D.; Lambert, C.; Piper, B.; et al. Risk-based water resources planning in practice: A blueprint for the water industry in England. Water Environ. J. 2020, 34, 441-454. [CrossRef]

31. Ofwat. Out in the cold. In Water Companies' Response to the 'Beast from the East'; Ofwat: Birmingham, UK, 2018.

32. CC Water. Customers' experiences of water supply interruptions following the freeze-thaw events of March Final Report. In The Consumer Council for Water; Systra: Birmingham, UK, 2018.

33. SDG 6. Ensure Availability and Sustainable Management of Water and Sanitation for All. Available online: https://sdgs.un.org/ goals / goal6 (accessed on 20 July 2021).

34. The World Health Organisation. Water, Sanitation, Hygiene, and Waste Management for COVID-19: Technical Brief, 03 March 2020. Available online: https:/ /apps.who.int/iris/handle/10665/331305 (accessed on 20 July 2021).

35. The World Health Organisation. Water, Sanitation, Hygiene, and Waste Management for SARS-CoV-2, the Virus that Causes COVID-19: Interim Guidance, 29 July 2020. Available online: https:/ /apps.who.int/iris/handle/10665/333560 (accessed on 20 July 2021).

36. The World Health Organisation. Hand Hygiene in the Community. Available online: https://www.who.int/infection-prevention/ campaigns/clean-hands/WHO_HH-Community-Campaign_finalv3.pdf (accessed on 20 July 2021).

37. Donde, O.O.; Atoni, E.; Muia, A.W.; Yillia, P.T. COVID-19 pandemic: Water, sanitation and hygiene (WASH) as a critical control measure remains a major challenge in low-income countries. Water Res. 2020, 116793.

38. Centre for Ecology and Hydrology. Drought Tool. Available online: https:/ / eip.ceh.ac.uk/droughts (accessed on 24 May 2021).

39. Barker, L.J.; Hannaford, J.; Chiverton, A.; Svensson, C. From meteorological to hydrological drought using standardised indicators. Hydrol. Earth Syst. Sci. 2016, 20, 2483-2505. [CrossRef]

40. Svensson, C.; Hannaford, J.; Prosdocimi, I. Statistical distributions for monthly aggregations of precipitation and streamflow in drought indicator applications. Water Resour. Res. 2017, 53, 999-1018. [CrossRef]

41. Met Office. Climate Maps. Available online: https://www.metoffice.gov.uk/research/climate/maps-and-data/uk-and-regionalseries (accessed on 2 February 2021).

42. Ofwat. Water Resources Market Information Guidance. Available online: https://www.ofwat.gov.uk/publication/waterresources-market-information-guidance-2/ (accessed on 5 May 2021).

43. Ofwat Water Resources Market Information. Available online: https://www.ofwat.gov.uk/regulated-companies/markets/ water-bidding-market/water-resources-market-information/ (accessed on 5 May 2021).

44. Anglian Water. 2019 Water Resources Management Plan. Available online: https://www.anglianwater.co.uk/about-us/ourstrategies-and-plans/water-resources-management-plan/ (accessed on 5 May 2021).

45. Southern Water. 2019 Water Resources Management Plan. Available online: https://www.southernwater.co.uk/our-story/waterresources-planning/water-resources-management-plan-2020-70 (accessed on 5 May 2021).

46. Severn Trent. 2019 Water Resources Management Plan. Available online: https:/ /www.stwater.co.uk/about-us/our-other-plans / water-resources-management-plan/ (accessed on 5 May 2021).

47. Dwr Cymru 2019 Water Resources Management Plan. Available online: https:/ /www.dwrcymru.com/en/our-services/water/ water-resources / final-water-resources-management-plan-2019 (accessed on 5 May 2021).

48. United Utilities. 2019 Water Resources Management Plan. Available online: https://www.unitedutilities.com/corporate/aboutus/our-future-plans/water-resources/water-resources-management-plan/ (accessed on 5 May 2021).

49. Northumbrian Water. 2019 Water Resources Management Plan. Available online: https://www.nwg.co.uk/responsibility/ environment/wrmp/current-wrmp-2015-2020/ (accessed on 5 May 2021).

50. Thames Water. 2019 Water Resources Management Plan. Available online: https://www.thameswater.co.uk/about-us/ regulation/water-resources (accessed on 5 May 2021).

51. South West Water. 2019 Water Resources Management Plan. Available online: https://www.southwestwater.co.uk/environment/ a-precious-resource/water-resources-management-plan/ (accessed on 5 May 2021). 
52. Wessex Water. 2019 Water Resources Management Plan. Available online: https://www.wessexwater.co.uk/environment/waterresources/management-plan (accessed on 5 May 2021).

53. Yorkshire Water. 2019 Water Resources Management Plan. Available online: https://www.yorkshirewater.com/about-us/ resources /water-resources-management-plan/ (accessed on 5 May 2021).

54. Artesia Consultancy. Collaborative Study. The Impact of COVID-19 on Water Consumption during February to October 2020-Final Report. Available online: https:/ / artesia.shinyapps.io/Artesia-Reports / (accessed on 20 July 2021).

55. Met Office. May 2020 Becomes the Sunniest Calendar Month on Record. Available online: https://www.metoffice.gov.uk/aboutus / press-office/news/weather-and-climate/2020/2020-spring-and-may-stats (accessed on 5 May 2021).

56. Environment Agency. Updating the Determination of Water Stressed Areas in England. Consultation Document. Available online: https://assets.publishing.service.gov.uk/government/uploads/system/uploads/attachment_data/file/958639/Water_ Stress_Consultation_V1.0_accessible.pdf (accessed on 24 May 2021).

57. Environment Agency. Monthly Water Situation Report: March 2020. Available online: https://assets.publishing.service.gov. uk/government/uploads/system/uploads/attachment_data/file/879174/Water_situation_March_2020.pdf (accessed on 24 May 2021).

58. Environment Agency. Monthly Water Situation Report: April 2020. Available online: https://assets.publishing.service.gov. uk/government/uploads/system/uploads/attachment_data/file/884710/Water_situation_April_2020.pdf (accessed on 24 May 2021).

59. Environment Agency. Monthly Water Situation Report: May 2020. Available online: https://assets.publishing.service.gov. uk/government/uploads/system/uploads/attachment_data/file/891601/Water_situation_May_2020.pdf (accessed on 24 May 2021).

60. Met Office. Spring and March Statistics. Available online: https://www.metoffice.gov.uk/binaries/content/assets/ metofficegovuk/pdf/weather/learn-about/uk-past-events/summaries/uk_monthly_climate_summary_202003.pdf (accessed on 5 May 2021).

61. Met Office. Spring and April Statistics. Available online: https://www.metoffice.gov.uk/binaries/content/assets/ metofficegovuk/pdf/weather/learn-about/uk-past-events/summaries/uk_monthly_climate_summary_202004.pdf (accessed on 5 May 2021).

62. Met Office Seasonal Forecast Assessment. Spring 2020. Available online: https://www.metoffice.gov.uk/binaries/content/ assets/metofficegovuk/pdf/weather/learn-about/uk-past-events/summaries/uk_monthly_climate_summary_spring_2020 _may.pdf (accessed on 5 May 2021).

63. Centre for Ecology and Hydrology. UK Hydrological Status Update-May 2020. Available online: https://www.ceh.ac.uk/newsand-media/blogs/uk-hydrological-status-update-may-2020 (accessed on 24 May 2021).

64. Open Government Licence. Available online: http://www.nationalarchives.gov.uk/doc/open-government-licence/version/3/ (accessed on 9 July 2021).

65. Centre for Ecology and Hydrology. UK Hydrological Status Update-Early August 2018. Available online: https://www.ceh.ac. uk/news-and-media/blogs/uk-hydrological-status-update-early-august-2018 (accessed on 24 May 2021).

66. Centre for Ecology and Hydrology. UK Hydrological Status Update-June 2020. Available online: https://www.ceh.ac.uk/newsand-media/blogs/uk-hydrological-status-update-june-2020 (accessed on 24 May 2021).

67. Environment Agency. Available online: https://assets.publishing.service.gov.uk/government/uploads/system/uploads/ attachment_data/file/871949/Water_situation_February_2020.pdf (accessed on 5 May 2021).

68. Met Office. UK Monthly Climate Summary Winter 2019-2020. Available online: https://www.metoffice.gov.uk/binaries/ content/assets/metofficegovuk/pdf/weather/learn-about/uk-past-events/summaries/uk_monthly_climate_summary_ winter_2020.pdf (accessed on 5 May 2021).

69. National Drought Group. Available online: https://www.gov.uk/government/news/national-drought-group-june-2020 -statement (accessed on 5 May 2021).

70. National Drought Group. Available online: https://www.gov.uk/government/news/national-drought-group-july-2020 -statement (accessed on 5 May 2021).

71. Environment Agency. Areas of Water Stress: Final Classification. Available online: https://www.iow.gov.uk/azservices/ documents /2782-FE1-Areas-of-Water-Stress.pdf (accessed on 24 May 2021).

72. Environment Agency. Water Stressed Areas: 2013 Classification. Available online: https://www.gov.uk/government/ publications / water-stressed-areas-2013-classification (accessed on 24 May 2021).

73. Environment Agency. Water Resources Planning Guidelines. Available online: https://www.gov.uk/government/publications/ water-resources-planning-guideline/water-resources-planning-guideline (accessed on 21 April 2021).

74. Met Office. Eastern England Climate. Available online: https://www.metoffice.gov.uk/binaries/content/assets/metofficegovuk/ pdf/weather/learn-about/uk-past-events/regional-climates/eastern-england_-climate---met-office.pdf (accessed on 24 May 2021).

75. Met Office. Southern England Climate. Available online: https://www.metoffice.gov.uk/binaries/content/assets/ metofficegovuk/pdf/weather/learn-about/uk-past-events/regional-climates/southern-england_-climate---met-office.pdf (accessed on 24 May 2021). 
76. Barclay, C. Agriculture and Climate Change. Available online: https://commonslibrary.parliament.uk/research-briefings/sn037 63/ (accessed on 24 May 2021).

77. Environment Agency. Water Supply and Resilience and Infrastructure. Available online: https://assets.publishing.service. gov.uk/government/uploads/system/uploads/attachment_data/file/504682/ea-analysis-water-sector.pdf (accessed on 24 May 2021).

78. Rey, D.; Holman, I.P.; Knox, J.W. Developing drought resilience in irrigated agriculture in the face of increasing water scarcity. Reg. Environ. Change 2017, 17, 1527-1540. [CrossRef]

79. WRSE. Future Water Resource Requirements for South East England-An Update. Available online: https://www.wrse.org.uk/ media/3h5p0dzo/future-water-resource-requirements-for-south-east-england-update-2021-final.pdf (accessed on 6 June 2021).

80. National Audit Office. Water Supply and Demand Management. Available online: https://www.nao.org.uk/report/watersupply-and-demand-management/ (accessed on 6 June 2021).

81. UK Parliament. Water Supply and Demand Management. Available online: https://publications.parliament.uk/pa/cm5801/ cmselect/cmpubacc/378/37802.htm (accessed on 6 June 2021).

82. Environment Agency. Meeting our Future Water Needs: A National Framework for Water Resources. Available online: https:// www.gov.uk/government/publications / meeting-our-future-water-needs-a-national-framework-for-water-resources (accessed on 6 June 2021).

83. Defra Policy Paper. Water Resources Planning: Managing Supply and Demand. 2017. Available online: https://www.gov.uk/ government/publications/water-resources-planning-managing-supply-and-demand (accessed on 5 May 2021).

84. National Risk Register 2020. Available online: https://www.gov.uk/government/publications/national-risk-register-2020 (accessed on 6 June 2021).

85. Doron, U.; Teh, T.H.; Haklay, M.; Bell, S. Public engagement with water conservation in London. Water Environ. J. 2011, 25, 555-562. [CrossRef]

86. Silvakumar, B. COVID-19 and Water. Stoch. Environ. Res. Risk Assess 2021, 35, 531-534. [CrossRef]

87. Water UK. Consultation Response on Per Capita Consumption. Available online: https://www.water.org.uk/publication/wateruk-recommendations-on-water-efficiency / (accessed on 30 June 2021).

88. Infrastructure Demand Quantitative Analysis for Scenarios of Behaviour Change. Report for National Infrastructure Commission. Ref: CCZZ20A. Available online: https://nic.org.uk/app/uploads/Steer-Infra-Demand-Quantitative-Analysis-May-2021.pdf (accessed on 30 June 2021).

89. Water UK. Be "Water Aware"—Tips for People at Home, Published 30 May 2020. Available online: https://www.water.org.uk/ news-item/be-water-aware-tips-for-people-at-home/ (accessed on 30 November 2020).

90. UK Parliament. Reducing Demand for Water. Available online: https://questions-statements.parliament.uk/written-statements/ detail/2021-07-01/hcws140 (accessed on 2 July 2021). 